Research Article

\title{
A study of serum psedocholinesterase levels following diazinon poisoning in relation to liver function-prognostic and therapeutic value
}

\author{
K. Swarnalatha, B. Surya Prakasa Rao, S. Sharon Sonia*
}

Department of Pharmacology, Kurnool Medical College, Kurnool-518002, India

Received: 24 June 2016 Accepted: 05 August 2016

*Correspondence to:

Dr. S. Sharon Sonia,

Email: drsharonsonias@gmail.com

Copyright: (c) the author(s), publisher and licensee Medip Academy. This is an open-access article distributed under the terms of the Creative Commons Attribution Non-Commercial License, which permits unrestricted non-commercial use, distribution, and reproduction in any medium, provided the original work is properly cited.

\begin{abstract}
Background: To study serum pseudo-cholinesterase (PChE) levels as an index of liver injury in individuals with diazinon poisoning with or without alcoholism. It gives the knowledge of the therapeutic efficacy and severity of liver dysfunction.

Methods: Blood samples were taken from normal male adults as control and PChE is estimated. Blood samples were taken from diazinon poisoning patients from local hospitals on the 1st day and on 5th day for pseudocholinesterase estimation. Another group of blood samples were taken on the 1st day and on the 5th day from diazinon poisoning patients with history of alcoholism serum PChE is estimated.

Results: Serum PChE was estimated among the normal healthy male adults as the normal value of enzyme for the various levels for comparison. Among 30 normal adults, the control value of PChE ranged between 125 and $321 \mu \mathrm{mol} / \mathrm{ml}$ with 212 as the mean. Following the treatment with atropine, PAM and blood transfusion, blood samples were estimated by 5th day among patients with diazinon. Their mean value was found to be $200 \mu \mathrm{mol} / \mathrm{ml}$. Among individuals with alcohol and diazinon poisoning, following the treatment, the serum PChE levels were raised comparatively on 1st day. The value is $100 \mu \mathrm{mol} / \mathrm{ml}$.

Conclusions: In diazinon poisoning without alcoholism, the prognostic and therapeutic efficacy of the drugs is better unlike in alcoholics. Hence a scope of necessitating the hepatoprotective measures is of consideration in the organophosphorous poisoning cases.
\end{abstract}

Keywords: Pseudocholinesterase enzyme, Diazinon poisoning, Alcoholism, Therapeutic index, Prognostic value

\section{INTRODUCTION}

In the clinical practice, pharmacotherapeutic agents are commonly used for health care purposes. There are incidences of drug abuse and misuse. Chronic alcohol addicts are at risk in organophosphorous poisoning. The organophosphorous cases are coming now and then to the local hospital. In these cases the serum pseudocholinesterase (PChE) levels in the liver and heart are decreased. It is inhibited because these poisons are irreversible anti cholinesterases. ${ }^{1}$

Further the liver function is affected by the alcoholism.So the enzyme levels are depressed. ${ }^{2}$ In both incidences, the liver and cardiac function are affected. There are many tests confirming liver dysfunction but routinely PChE estimation is not carried out though it is an index of liver function. ${ }^{3}$

Since many years it is noticed that among poisoning cases, diazinon poisoning cases are considerably more. Several factors are responsible for diazinon poisoining. It is known to be depress PChE and thus liver function. ${ }^{4}$ It is also noticed that much work has not been done on serum PChE except in the scolene apnoea as compared to studies on cardiac function. ${ }^{5}$ Hence serum PChE levels can be estimated as an index of liver injury in diazinon poisoning cases with or without alcoholism. Hence it is worth to study PChE levels in these poisoning cases coming to local hospital. This study will contribute useful data in pharmacotherapeutic efficiency of treatment. The objective of the study was to evaluate the role of serum 
PChE levels as an index of liver dysfunction and to know the therapeutic value of the treatment of diazinon poisoning. Finally it helps to know the prognostic and therapeutic efficacy of drugs like anticholinergics and oximes.

\section{METHODS}

Blood samples were taken from normal adult males as control and serum PChE is estimated. Blood samples were taken on the 1st day and on 5th day from diazinon poisoning patients from local hospitals.

Blood samples were taken from patients who are admitted in the local hospital with diazinon poisoning and history of alcoholic abuse for estimation of serum PChE on the 1st day and on the 5th day. Serum PChE is estimated by Delaherga Yersinik Hopper method. ${ }^{6}$

\section{Estimation of serum pseudocholinesterase (PChE)}

\section{Principle}

PChE reacts with large doses of acetylcholine in the presence of hydroxylamine. Hydroxylamine in alkaline solution reacts with the unhydrolysed, acetylated portion of acetylcholine, to form hydroxamic acid. Hydroxamic acid gives red colour with ferric chloride. This red colour is estimated colorimetrically. ${ }^{7}$

\section{Reagents}

1. Buffer solution: 10.3 gms sodium barbitone dissolved in about $300 \mathrm{ml}$ of water and $60 \mathrm{ml}$ of normal hydrochloric acid. Crystals of barbitone will be formed. $5.3 \mathrm{gms}$ of anhydrous sodium carbonate is added, stirred and warmed gently until solution was completely formed, which will be cooled to room temperature and made up to $500 \mathrm{ml}$.

2. Salt mixture $4.2 \mathrm{gm}$ of anhydrous magnesium chloride and $0.2 \mathrm{gm}$ of potassium chloride were dissolved and made up to $100 \mathrm{ml}$.

3. Acetylcholine bromide: $11.3 \mathrm{gms}$ of acetylcholine bromide were dissolved and made up to $100 \mathrm{ml}$. This gives $0.5 \mathrm{M}$ solution.

4. Acetylcholine bromide-buffer salt mixtureimmediately before use, 8 volumes of buffer solution and 1volume each of acetylcholine bromide solution and salt mixture were mixed.

5. Hydroxylamine hydrochloride $14 \%$ was prepared in water

6. Sodium hydroxide $14 \%$ was prepared in water

7. Alkaline hydroxylamine: equal volumes (5) and (6) were mixed.
8. Ferric chloride solution: 10 gms of ferric chloride were dissolved in one litre of $0.02 \mathrm{~N}$ hydrochloric acid.

9. Hydrochloric acid $5 \mathrm{~N}$.

10. Acetylcholine bromide, standard solution: $0.5 \mathrm{M}$ solution was diluted in 1 in 10 (this contained 50 $\mu \mathrm{mol} / \mathrm{ml})$

\section{Procedure}

$0.2 \mathrm{ml}$ of centrifuged serum was pippetted into one test tube and $0.2 \mathrm{ml}$ of distilled water into another $0.2 \mathrm{ml}$ tube. $0.2 \mathrm{ml}$ of bromide buffer salt mixture previously warmed to $37^{\circ} \mathrm{C}$ was added to each test tube and incubated for 1 hour at $37^{\circ}$ C. Later alkaline hydroxylamine solution was added. $6 \mathrm{ml}$ of $0.5 \mathrm{~N} \mathrm{HCl}$ was added after waiting for a minute. The test tubes were stoppered and inverted 3 times $0.5 \mathrm{ml}$ of each was taken into separate centrifuge tube and $1 \mathrm{ml}$ of ferric chloride solution is added.

\section{Calculation}

Unit of activity of AChE or PChE corresponds to the hydrolysis of 1 micromole of acetylcholine per ml serum

Therefore units of cholinesterase/ml of serum=

$$
\frac{\text { Reading of control }- \text { Reading of test }}{\text { Reading of standard }} \times 500
$$

The values are the micromoles of acetylcholine bromide hydrolysed by $1 \mathrm{ml}$ of PChE.

All the results of above estimations are tabulated for comparative study and analysis in relation to the influence of poisoning and alcoholism on the liver function following drug therapy.

\section{RESULTS}

Serum PChE was estimated among the normal healthy male adults as the normal value of enzyme for the various levels for comparison as given in Table 1.

Among 30 normal adults the control value of serum pseudo cholinesterase ranged between 125 and 321 $\mathrm{mg} / \mathrm{ml}$ with 212 as the mean.

The mean values of pseudocholinesterase among patients with diazinon organophosphorous poisoning is $120 \mu \mathrm{g}$.

Following the treatment with atropine PAM, blood transfusion by 5th day blood samples were estimated among diazinon poisoning patients their mean value was found to be $200 \mu \mathrm{g}$. Among individuals with alcohol and diazinon poisoning following the treatment on 1st day. The serum pseudo cholinesterase levels were raised comparatively. The Value is 100. 
Table 1: Estimation of serum PChE for the various levels for comparison.

\begin{tabular}{|c|c|c|c|c|c|}
\hline S.No & Controls & $\begin{array}{l}\text { Organophosphorus } \\
\text { poisoning 1st day }\end{array}$ & $\begin{array}{l}\text { Organophosphorus } \\
\text { poisoning 5th day }\end{array}$ & $\begin{array}{l}\text { Organophosphorus } \\
\text { poisoning 1st day } \\
\text { (alchohol) }\end{array}$ & $\begin{array}{l}\text { Organophosphorus } \\
\text { poisoning 5th day } \\
\text { (alchohol) }\end{array}$ \\
\hline 1 & 321 & 162 & 206 & 75 & 87 \\
\hline 2 & 232 & 113 & 220 & 104 & 123 \\
\hline 3 & 152 & 127 & 248 & 110 & 110 \\
\hline 4 & 154 & 136 & 196 & 101 & 102 \\
\hline 5 & 175 & 127 & 196 & 106 & 97 \\
\hline 6 & 160 & 107 & 177 & 81 & 122 \\
\hline 7 & 175 & 116 & 173 & 116 & 94 \\
\hline 8 & 285 & 123 & 206 & 102 & 89 \\
\hline 9 & 172 & 155 & 195 & 111 & 121 \\
\hline 10 & 175 & 108 & 210 & 81 & 102 \\
\hline 11 & 165 & 141 & 182 & 117 & 117 \\
\hline 12 & 163 & 131 & 238 & 108 & 103 \\
\hline 13 & 174 & 120 & 202 & 77 & 115 \\
\hline 14 & 190 & 104 & 221 & 101 & 59 \\
\hline 15 & 218 & 119 & 195 & 91 & 119 \\
\hline 16 & 194 & 123 & 197 & 102 & 147 \\
\hline 17 & 216 & 96 & 214 & 95 & 131 \\
\hline 18 & 248 & 129 & 211 & 96 & 128 \\
\hline 19 & 233 & 109 & 178 & 79 & 105 \\
\hline 20 & 310 & 122 & 169 & 94 & 114 \\
\hline 21 & 181 & 120 & 178 & 115 & 115 \\
\hline 22 & 274 & 107 & 172 & 102 & 112 \\
\hline 23 & 273 & 119 & 201 & 77 & 93 \\
\hline 24 & 199 & 132 & 192 & 140 & 103 \\
\hline 25 & 240 & 88 & 193 & 133 & 107 \\
\hline 26 & 140 & 146 & 173 & 103 & 100 \\
\hline 27 & 125 & 173 & 216 & 94 & 127 \\
\hline 28 & 229 & 144 & 209 & 86 & 161 \\
\hline 29 & 278 & 119 & 198 & 117 & 84 \\
\hline 30 & 309 & 134 & 220 & 86 & 113 \\
\hline
\end{tabular}

Following the treatment of diazinon poisoning on the 5th day in the serum PChE is variable in the alcoholicdiazinon poisoning the rise is not satisfactorily $110 \mathrm{mcmol} / \mathrm{m}$. This shows highly significant.

Control values of enzyme among normal adults in the present study were comparable with the values mentioned by Western authors. The values of Indian authors are somewhat lower. Values of Indian women are lower than men. The mean values of PChE among patients with diazinon poisoning are $120 \mu \mathrm{mol} / \mathrm{ml}$.

\section{Effect of organophosphorous compound poisoning and treatment}

Following treatment with atropine, PAM and blood transfusion blood samples were estimated by 5 th day among diazinon poisoning patients. Their mean value was found to be $200 \mu \mathrm{mol} / \mathrm{ml}$.
There is a tendency of rise of level of serum PChE in the non-alcoholics with diazinon poisoning. Recovery of serum PChE levels towards normal value is satisfactory. Among individuals with alcohol and diazinon poisoning, following the treatment on 1st day, the serum PChE is comparatively lower. The value is $100 \mu \mathrm{mol} / \mathrm{ml}$. This unsatisfactory response following treatment is due to additional hepatotoxicity of alcohol and diazinon poisoning.

The mean value of blood samples of both the groups of diazinon poisoning was comparatively less than normal adult serum PChE value. Due to the poisoning, adverse effects are seen in CV function .The liver injury results in reduction of serum PChE levels. Hence due to severe injury by alcoholism, the hepatotoxicity of the diazinon poisoning is enhanced. Values of PChE among alcoholics was compared to controls. Serum $\mathrm{ChE}$ values showed a statistically significant lowering shared to controls though 
the mean values were within described normal range. There was significant lowering of the time with increased consumption.

\section{Statistical evaluation}

The values of serum PChE in normal healthy male adults are compared with the values in both diazinon poisoning patients and diazinon poisoning in alcoholics. The reduction levels of both alcohol and diazinon also highly significant. On the 5th day, the levels of serum PChE are compared with the levels on the 1st day of poisoning. There is a variable rise in the levels of serum PChE.

\section{DISCUSSION}

There are many liver function tests, but a problem is the selection of test having satisfactory sensitivity and specificity to minor degrees of liver dysfunction relative to clinical evidence of liver damage.

This enzyme activity is stable and does not change by environment. The effect of organophosphorous compounds and alcoholism on the liver can be inferred by the estimation of PChE. This method has not achieved wide popularity as liver function test due to variation of normal values. This disadvantage is overcome in the present study by considering the $1^{\text {st }}$ sample level comparable with 2 nd blood sample to assess the effects.

Normal serum PChE levels in young healthy male adults 25-45 years age group are selected for the purpose of estimation of PChE enzyme as control values for comparison. PChE was estimated by Delaherga Yersinik Hopper method. ${ }^{6}$ The mean PChE levels in adults is 212 $\mu \mathrm{mol} / \mathrm{ml}$ of serum.

As soon as patients were brought to casualty with all symptoms confirming patient as organophosphorous compound, blood sample is taken for the PChE estimation. Thus 30 samples were estimated. The mean value of PChE level is calculated. It was $120 \mu \mathrm{mol} / \mathrm{ml}$.

After the treatment with atropine and oximes on the 5 th day the blood samples were taken for estimation and the values calculated. The mean values are $200 \mu \mathrm{mol} / \mathrm{ml}$.

Blood samples taken from organophosphorous compounds poisoning with alcoholism to estimate serum PChE levels from 30 patients. The mean value is 80 $\mu \mathrm{mol} / \mathrm{ml}$. Later the treatment was given by administering atropine, oximes and necessary fluids .After the treatment on the 5th day, another blood sample was taken for estimating serum PChE levels. The mean value is 100 $\mu \mathrm{mol} / \mathrm{ml}$. In these cases the fresh compatable blood transfusion was also given atropine $2 \mathrm{mg}$ was given every $10 \mathrm{~min}$ till the signs of atropinisation were seen. Pralidoximine $1 \mathrm{gm}$ was also given12th hourly.
Following the organophosphorous compound poisoning, the quantity of ingestion and time of presence of poison in the body influences the target vital organs, which results in the appearance of severe clinical symptoms and signs. Following the diazinon poisoning most of the individuals exhibit cardiovascular symptoms predominantly and biochemically liver dysfunction effects

Following diazinon poisoning in alcoholics, the most vulnerable target organ is liver resulting into hepatotoxicity. Following the specific treatment with atropine, oximes and blood transfusion, the resultant response to recover the normal enzyme levels varies because of the hepatotoxicity due to alcoholism. Hence hepatoprotective therapeutic measures are to be thought of in poisoning cases in alcoholics.

The results show that there is reduction of serum PChE levels in comparison with normal values. The reduction of serum PChE is more in the individuals of diazinon poisoning associated with alcoholism. Here the reason may be due to alcoholism causing additional injury to liver.

Following the treatment with atropine, oxime, blood transfusion by 5th day there is a tendency of rise of level of seum PChE. In the non-alcoholism individuals with diazinon poisoning, the serum PChE levels showed satisfactory rise towards normal levels. Among alcoholics and diazinon poisoning, following the treatment in $1 \mathrm{st}$ day the levels were not raised comparatively. This unsatisfactory response following treatment is due to additional effect of alcoholic he patotoxicity and diazinon poisoning

Following the treatment of diazinon poisoning, on the 5th day, the rise the serum PChE level is not to a satisfactory level, in the alcoholics with diazinon poisoning. This shows highly significant effect.

\section{CONCLUSION}

There is synergistic result by the combination ofatropine and PAM in connection with recovering PChE levels. The usage of atropine combination therapy is responsible for good antagonism of diazinon poisoning. Being natural antagonist of Ach, the recovered levels of serum PChE levels are useful in controlling the excess cholinergic activity. This is due to recovering of liver function which has resulted due to an antidote like action of the treatment of synergistic action of atropine and PAM. Alcoholism associated diazinon poisoning doesn't show satisfactory recovery because of the additional liver damage due to alcoholism. Hence a scope of necessitating the hepatoprotective measures is of considerable value in the organophosphorous poisoning cases in alcoholics. 
Funding: No funding sources

Conflict of interest: None declared

Ethical approval: The study was approved by the Institutional Ethics Committee

\section{REFERENCES}

1. Ecobichon DJ, Kalow W. Action of organophosphorous compounds upon esterases of human liver. Canadian journal of bi ochem. 1937;41:1537-46.

2. Kasper D, Fauci A, Hauser S. Harrisons Principles of Internal Medicine 19th edition. 2651-2658.

3. Fekete T, Marcu A. Behavior of serum pseudo cholinesterase in fasting therapy of obesity study. Cercel medintern. 1970;12:301-4.

4. Pseudo cholinesterase activity as a guide to prognosis in malnutrition. American $\mathrm{J}$ clini pathol. 1973;50:712-6.
5. Kar NC, Pearson CM. Cholinesterase and esterase activity in normal and dystrophic muscle biochemical. Colorimetric methods of analysis. MED. 1973;7:4729.

6. Viswanathan M, Srinivasan K. Poisoning by lung poison. JMA. 1968;39:345.

7. Fenichel GM, Kibler WB, Olson WH, Dettbarn WD. Chronic inhibition of cholinesterase as a cause of myopathy. Nuerology (Minsue cap). 1972;22:192633.

Cite this article as: Swarnalatha K, Rao BSP, Sonia SS. A study of serum psedocholinesterase levels following diazinon poisoning in relation to liver function-prognostic and therapeutic value. Int J Basic Clin Pharmacol 2016;5:1937-41. 